\title{
Eye and Ear Finding
}

National Cancer Institute

\section{Source}

National Cancer Institute. Eye and Ear Finding. NCI Thesaurus. Code C36283.

Symptoms, physical examination results, and/or laboratory test results related to the organs of special sense. 